\title{
A Novel Technology for Processing Urban Waste Compost as a Fast-Releasing Nitrogen Source to Improve Soil Properties and Broccoli and Lettuce Production
}

\section{Fabio Olivieri de Nobile}

Barretos Educational Foundation University Centre: Centro Universitario da Fundacao Educacional de Barretos https://orcid.org/0000-0001-9423-8420

\section{Alexander Calero Hurtado ( $\sim$ alexcalero34@gmail.com )}

Universidade Estadual Paulista Julio de Mesquita Filho - Campus de Jaboticabal https://orcid.org/0000-00016536-2908

\section{Renato de Mello Prado}

Universidade Estadual Paulista Julio de Mesquita Filho - Campus de Jaboticabal https://orcid.org/0000-00031998-6343

\section{Henrique Antunes de Souza}

Brazilian Agricultural Research Corporation https://orcid.org/0000-0002-2209-4285

\section{Maria Gabriela Anunciação}

Centro Universitario da Fundacao Educacional de Barretos https://orcid.org/0000-0002-3892-7106

\section{Luiz Fabiano Palaretti}

Universidade Estadual Paulista Julio de Mesquita Filho - Campus de Jaboticabal https://orcid.org/0000-00015107-6038

\section{Leticia Ane Sizuki Nociti Dezem}

Barretos Educational Foundation University Centre: Centro Universitario da Fundacao Educacional de Barretos https://orcid.org/0000-0002-5160-6112

\section{Research Article}

Keywords: Brassica oleracea L., Domestic wastes, Lactuca sativa L., Nitrogen content, Organic fertilizer, Soil fertility

Posted Date: March 2nd, 2021

DOl: https://doi.org/10.21203/rs.3.rs-262163/v1

License: (c) (7) This work is licensed under a Creative Commons Attribution 4.0 International License. Read Full License 
Version of Record: A version of this preprint was published at Waste and Biomass Valorization on March 20th, 2021. See the published version at https://doi.org/10.1007/s12649-021-01415-z. 


\section{Abstract}

Purpose: This study evaluated nitrogen $(\mathrm{N})$ mineralization dynamics in three soils after the addition of heattreated urban waste amendments or urban waste compost (UWC). The effects of UWC and urea on soil properties and broccoli and lettuce production were compared.

Methods: The first $\mathrm{N}$ mineralization experiment was conducted in a factorial arrangement $(4 \times 3)$, as a randomized complete block design (RCBD), with three replicates. Four UWC doses: 12.5, 25.0, 37.5, and $50.0 \mathrm{mg}$ $\mathrm{dm}^{-3}$ were applied to three soils: sandy Ustoxic Quartzipsamment (QS), intermediate-texture red Ultisol (US), and clayey red Oxisol (OS), during eight incubation periods $(0,7,14,28,42,56,70$, and 84 days). In the second experiment, the effects of UWC and urea fertilizer on soil properties were compared. The growth of broccoli and lettuce plants was evaluated (experiments 3 and 4). The treatments (Experiments 2-4) followed a factorial arrangement ( $4 \times 2 ; \mathrm{RCBD}$; three replicates), using OS soil. Four $\mathrm{N}$ doses (as for experiment 1 ) were combined with two $\mathrm{N}$ sources (UWC and urea).

Results: The processed UWC application proportionally increased the $\mathrm{N}$ mineralization rate by $72 \%$ in QS, $54 \%$ in US, and $66 \%$ in OS. Furthermore, UWC application enhanced soil properties ( $\mathrm{pH}$ and nutrient availability), compared with urea fertilizer, and improved $\mathrm{N}$ uptake, resulting in higher fresh biomass production in broccoli and lettuce plants (50.0 and $37.5 \mathrm{mg} \mathrm{dm}^{-3}$, respectively).

Conclusions: Our findings suggest that heat-treated UWC is an economical, viable, and efficient fertilizer to improve soil properties and short-cycle vegetable crop productivity.

\section{Statement Of Novelty}

Population growth and intensive urbanization are the leading causes of the production and accumulation of urban waste. Processing urban waste into urban waste compost (UWC) is an innovative way of recycling organic waste from cities. This study's importance, both nationally and internationally, relates to the use of novel technology to eliminate sources of soil- and water-polluting organic waste that can harm animal and human health. It also contributes to the potential reduction of the use of inorganic $\mathrm{N}$ sources such as urea, a nonrenewable and finite resource, the production of which depends on natural gas. This study suggests that heattreated UWC is an economical, viable, and efficient fertilizer to increase the productivity of short-cycle vegetable crops.

\section{Introduction}

Population growth and intensification of urbanization are the leading causes of increased production and urban waste accumulation [1]. Aerobic composting is an alternative approach for urban solid waste disposal, promoting degradation of the putrescible organic fraction and producing compost [2], which can be utilized in agriculture as an organic fertilizer source $[3,4]$. Some research has shown the benefits of using composts and other amendments to enhance soil chemical ( $\mathrm{pH}$ and nutrient content) and biological properties such as soil microbial populations and plant growth [5]. Nonetheless, chemical compounds found in urban waste composts, particularly nitrogen $(\mathrm{N})$, are not readily available to plants $[6,7]$, so it is necessary to determine the availability of this element in the soil [8]. 
Understanding the $\mathrm{N}$ cycle in soils is a basic requirement for identifying management options that couple soil cycle in space and time. This is required as $\mathrm{N}$ cycling affects $\mathrm{N}$ availability to the plant, as well as microbial activity [9]. With regard to urban waste amendment, there are few detailed studies about how this impacts $\mathrm{N}$ mineralization and soil properties and thus affects crop production [10]. Soil N supply from organic amendments depends on both the initial availability of inorganic $N(I N)$ in the amendments and mineralization rate [11]. This means that organic amendments can either be a source of plant-available $\mathrm{N}$ or compete with plants for it. To successfully manage nutrient cycling from organic amendments, it is necessary to know their decomposition rates and their influence on $\mathrm{N}$ processes within the soil $[5,12]$.

Nitrogen mineralization is a complex biological process. The amount of $\mathrm{N}$ released depends on multiple factors such as the chemical composition of the organic matter (e.g., $\mathrm{N}$ content, C:N ratio, contents of cellulose and hemicelluloses, lignin, and polyphenols) $[13,14]$, and on the physical, chemical, and biological properties of soil microbes [15]. The $\mathrm{N}$ mineralization of urban wastes can be affected by high phosphorus $(\mathrm{P})$ concentrations, heavy metals, pathogens, and other harmful substances $[16,17]$. Previous studies have determined that the mineralization rate of urban waste compost (UWC) is relatively low [18]. Organic composts with high $\mathrm{N}$ concentrations and low C:N ratios mineralize sufficient $\mathrm{N}$ to satisfy plant growth $[15,19]$. Conversely, $\mathrm{N}$ can be immobilized in organic composts with lower $\mathrm{N}$ contents and higher C:N ratios [14, 15].

For effective utilization of urban waste as compost, the $\mathrm{N}$ mineralization rate is a suitable criterion for defining the maximum $\mathrm{N}$ doses to be applied under particular soil, climate, and crop conditions, in the absence of other restrictive factors. However, the interactions and effects of such factors are not yet well understood in tropical soils. This is an important matter for consideration because of the need to use high-quality organic wastes as an $\mathrm{N}$ source for crops. Therefore, information on the agricultural performance of UWC is important for growing vegetable crops that are widely cultivated in the green belts located around big metropolises that produce large amounts of urban solid waste. Additionally, there are recent reports that UWC increases productivity in broccoli [20], lettuce [21], and potatoes [6].

The use of UWC can be an efficient alternative for agricultural production. To substantiate the use of UWC to improved soil and vegetable crop production, this study specifically aims to (i) quantify the effects of different UWC amendments on inorganic $\mathrm{N}$, net mineralizable $\mathrm{N}$, and $\mathrm{N}$ mineralization rates; and (ii) investigate their improvement effects on soil properties and broccoli and lettuce productivity in comparison with urea. To meet these objectives, we tested the following hypothesis: (1) N mineralization rate in UWC amendments is relatively fast, although it varies with soil type, (2) UWC application is a more efficient N source than urea due to decrease soil acidity and increases soil nutrient availability, and (3) the contribution of UWC to broccoli and lettuce production would be more strongly related to increasing $\mathrm{N}$ availability.

\section{Material And Methods}

\subsection{Trials and Setup}

Controlled experiments were conducted at the University Center of the Educational Foundation of Barretos, Barretos, Sao Paulo, Brazil. The purpose of the trials described in Section 2.1 was to determine the effects of UWC on $\mathrm{N}$ mineralization rate, soil properties, and the growth of broccoli and lettuce. The initial screenings for $\mathrm{N}$ mineralization of UWC in three different soils were carried out in a soil fertility laboratory (Experiment 1). The 
beneficial effects of UWC on soil properties compared to urea fertilizer were validated in OS soil (Experiment 2). Finally, the agricultural effect of UWC on the growth and nutritional quality of greenhouse-grown lettuce and broccoli plants was determined in comparison to the urea fertilizer (Experiments 3 and 4).

\subsubsection{Soil Collection and Chemical and Physical Characteristics}

The soils used had different textures, according to the FAO criteria [22]: (1) clayey red Oxisol (OS), equivalent to eutrudox; (2) intermediate-textured red Ultisol (US); and a Sandy Ustoxic Quartzipsamment soil (QS), equivalent to hapludult, according to the IUSS Working Group WRB [22], respectively. The OS and US soils were collected in Barretos, São Paulo, Brazil: RO in a native pastured-forest area, and RU in a pastured area, whereas the QS soil was sampled in Jaboticabal, SP, Brazil, in a pastured area. Approximately $50 \mathrm{~kg}$ of each soil was collected from the 0-0.2 m layer. Soil samples were air-dried, sieved ( $4 \mathrm{~mm})$, and stored in a well-ventilated storage room. Subsamples were collected for chemical analysis $(\mathrm{pH}, \mathrm{H}+\mathrm{Al}, \mathrm{P}, \mathrm{Ca}$, and $\mathrm{Mg}$ ) using the methods described by Raij et al. [22], and the physical (particle size) analysis was performed following the methodology described by Embrapa [23]; these data are provided in Table S1.

\subsubsection{Description, Composition, and Classification of Heat-treated Urban Waste Compost}

The urban waste compost used in this study was derived from the organic fraction of domestic garbage collected in the city of Araraquara, São Paulo, Brazil. The urban waste composting process involves three main steps. It begins with rough screening of the waste to remove non-organic materials (e.g., plastic and glass), and retain only the organic part. Thereafter, the material is moistened with water to $55 \%$ humidity to stimulate the decomposition phase. The third phase is performed in a yard where organic waste is deposited on wooden pallets in windrows to enable static aerobic decomposition to occur.

The aeration technique employed consists of passive aeration using perforated plastic tubes below each windrow, without any type of compressor. A constant renewal of hot to cold air promotes aeration of the entire mass contained in each windrow. The windrows are moistened with leachate, promoting the reintegration of leachate into the process. The temperature and $\mathrm{pH}$ value of the compost during composting started at $60{ }^{\circ} \mathrm{C}$ and 5.0 , respectively, and reached $35^{\circ} \mathrm{C}$ and 8.5 , respectively. After stabilization of the organic matter, the material deposited in the windrows is removed and sieved $(<15 \mathrm{~mm})$. Then, the UWC is dried in ovens at temperatures of 65 to $70{ }^{\circ} \mathrm{C}$ for 3 days, following which the compost is powdered $(<0.6 \mathrm{~mm})$ to obtain a final homogeneous product.

The chemical characteristics of UWC were determined using the methodology of Abreu et al. [24] according to the presence of toxic elements (e.g., heavy metals). The environmental aspects related to the reuse of residues in agriculture are provided in Table S2. The UWC was classified as a class-C simple organic fertilizer, according to the Normative Instruction No. 25, 2009, of the Brazilian legislation, and by this same legislation, the particle size showed the following characteristics: $0.04 \%$ retained on the NBR \#10 sieve mesh size, $26.51 \%$ on the NBR \#20 sieve, $60.25 \%$ on the NBR \#50 sieve, and $13.20 \%$ retained on the NBR \#50 sieve. The gravimetric moisture of the compost was $4 \%$ [25]. 


\subsection{Incubation Experiments}

\subsubsection{Determination of Nitrogen Mineralization Rate}

Experiment 1. This experiment was carried out under laboratory conditions to evaluate the $\mathrm{N}$ mineralization in three different soils (QS, US, and OS) fertilized with different amendments of UWC during an incubation period of 84 days. Determination of $\mathrm{N}$ mineralization rate was performed according to the methodology proposed by Coscione and Andrade [26]. Four UWC doses (12.5, 25.0, 37.5, and $\left.50.0 \mathrm{mg} \mathrm{dm}^{-3}\right)$ were mixed with the three soil samples (QS, US, and OS) and placed in $0.25-\mathrm{dm}^{3}$ polyethylene bottles. Each bottle contained $100 \mathrm{~g}$ of soil mixed with the corresponding compost dose. All soil and UWC dose combinations were prepared in triplicate. During the 12 weeks of incubation, the samples were analyzed at the following times: $0,7,14,28,42,56,70$, and 84 days. The moisture of the samples was adjusted to $70 \%$ of soil water-holding capacity by adding deionized water. The temperature was controlled to $25-28^{\circ} \mathrm{C}$ and monitored daily after the first sample was weighed. The trial was a factorial $(4 \times 3)$ randomized complete block design $(\mathrm{RCBD})$ with three replications.

To determine mineral $\mathrm{N}(\mathrm{MN}), 3 \mathrm{~g}$ of soil mixture was extracted in $15 \mathrm{~mL} 1 \mathrm{M} \mathrm{KCl}$ with $1 \mathrm{~h}$ of shaking. The soil mixture was filtered through Whatman 41 filter paper (MN 616; Whatman International, Maidstone, UK), and the extract was stored at $-18^{\circ} \mathrm{C}$ until analysis. The IN concentration of each soil sample was then analyzed by flow injection analysis (FIA, Foss Tecator; FOSS Analytical, São Paulo, Brazil) [27] and was calculated based on the dry soil weight after $0,7,14,28,42,56,60$, and 84 days of the incubation period.

Removal of mineral $\mathrm{N}$ from the soil solution by denitrification or immobilization was not considered, and only net $\mathrm{N}$ mineralization (NNM) was estimated. The NNM of each soil mixture sample was calculated as the fit of several kinetic models to the evolution of soil mineral $\mathrm{N}$. The NNM was described by a zero-order kinetic model as follows:

$$
N(t)=N_{0}+k \times t
$$

where $N(t)$ is the amount of MN at time $t$ (days), $N_{0}$ is the initial amount of mineral N $\left(\mu \mathrm{g} \mathrm{N} \mathrm{g}^{-1}\right.$ soil), and $\mathrm{k}_{0}$ is the zero-order $\mathrm{N}$ mineralization rate $\left(\mu \mathrm{g} \mathrm{g}^{-1} \mathrm{~d}^{-1} \mathrm{~N}\right)$.

The mineralized $\mathrm{N}$ of the UWC doses was calculated as described previously by Mohanty et al. [28]. The percentage of total $\mathrm{N}$ mineralized (\%TNM) from each UWC dose at the end of the incubation time (84 days) was calculated as described by Azeez and Van Averbeke [29], as follows:

$$
\% T N M=\left(\frac{N M(\text { doses })-N M(\text { control })}{\text { total } N \text { applied }}\right) \times 100
$$

where $N M$ is mineralized $\mathrm{N}$ and $N$ is the total $\mathrm{N}$ applied in the UWC doses.

\subsubsection{Determination of Soil Properties after Urban Waste Compost and Urea Treatments}


Experiment 2. This experiment was carried out under laboratory conditions to evaluate soil properties and fertility in an OS soil fertilized with UWC or urea and incubated for 30 days. Pots were used in this experiment and were distributed in a factorial arrangement $(4 \times 2)$ in an RCBD, with four replications. Four $\mathrm{N}$ doses $(12.5,25.0,37.5$, and $50.0 \mathrm{mg} \mathrm{dm}^{-3}$ ) and two different $\mathrm{N}$ sources (UWC and urea) were applied. Each experimental unit consisted of $0.25-\mathrm{dm}^{3}$ polyethylene pots filled with the OS soil. Phosphorus and potassium were equilibrated and applied to all the treatments, according to the chemical soil analysis results (Table S1), and following the recommendations of Trani and Raij [30]. This was accomplished by mixing $5 \mathrm{~g}$ of a 0-25-25 compound fertilizer with the soil in each pot.

After 30 days of incubation, six randomized soil subsamples were collected from each pot, air-dried, and analyzed for the following soil parameters: $\mathrm{pH}$, total acidity $(\mathrm{H}+\mathrm{Al})$, exchangeable calcium $(\mathrm{Ca})$, magnesium $(\mathrm{Mg})$, and $\mathrm{P}$ resin. After drying, the samples were defragmented and passed through a 2-mm mesh, homogenized, and stored in a refrigerator for chemical analysis, following the methodology described by Raij et al. [22]. The soil pH was measured in $\mathrm{CaCl}_{2}$ using a $\mathrm{pH}$ meter. Total acidity $(\mathrm{H}+\mathrm{Al})$ was determined in a calcium acetate solution. The $\mathrm{P}$ resin and exchangeable bases, extracted with ion exchange resin, were quantified using the colorimetric method and a standard curve previously obtained using a visible spectrophotometer (SP-1105; Ningbo Hinotek Technology, Shanghai, China). Exchangeable $\mathrm{Ca}^{2+}$ and $\mathrm{Mg}^{2+}$ were extracted in $1 \mathrm{M}$ ammonium acetate saline solution at pH 7.0 and quantified using an atomic absorption spectrophotometer (Varian ${ }^{\circledR}$ SpectrAA, 50 B; Varian Medical Systems Australasia, Belrose, NSW, Australia).

\subsection{Determination of Soil Properties after UWC and Urea Treatments}

Experiments 3 and 4. Broccoli (Brassica oleracea L. cv. 'Avenger') and lettuce (Lactuca sativa L. cv. 'Amelia') crops were grown in a glass greenhouse under natural light conditions, with day/night temperatures of $24{ }^{\circ} \mathrm{C} / 18{ }^{\circ} \mathrm{C}( \pm$ $3.5^{\circ} \mathrm{C}$ ), a $10 \mathrm{~h}$ day/14 $\mathrm{h}$ night photoperiod, and $70-75 \%$ relative humidity. Seeds of both plant species were sown in 128 cell polystyrene trays containing a vermiculite mixture (3:1) and were irrigated three times per day for 15

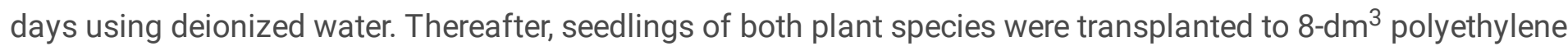
pots filled with the OS soil, with three seedlings per pot. Ten days after transplanting (DAT), plants were thinned to one per pot to evaluate growth. Two pot experiments were carried out, and eight treatments were arranged factorially $(2 \times 4)$ in an RCBD, with four replicates $(n=4)$ for each experiment, giving a total of 64 pots (32 for each crop). The two N sources (UWC and urea) were applied to pots in four different doses: $12.5,25.0,37.5$, and $50.0 \mathrm{mg} \mathrm{dm}^{-3}$.

Lettuce shoots were harvested after 30 DAT, while the broccoli was harvested after 90 DAT. The plant stems were cut at soil level to evaluate the fresh biomass, and the samples were then dried in a forced-air oven (Tecnal ${ }^{\circledR} \mathrm{TE}$ 394-3; Tecnal Scientific Equipment, Piracicaba, Brazil) at $65^{\circ} \mathrm{C}$ until a constant mass was obtained. The dried shoots were then pulverized using a Wiley mill equipped with a stainless-steel chamber and blades (Marconi ${ }^{\circledR}$ MA 360; Marconi Equipment Laboratories Ltd., Piracicaba, Brazil). The total N concentration was determined using the Kjeldahl method [31]. Based on the concentrations of $\mathrm{N}$ in the aerial parts of both plant species and their respective values of dry biomass, the $\mathrm{N}$ accumulations of these elements were calculated (mg per plant).

\subsection{Data analysis}

Page $7 / 20$ 
Data were analyzed using the Shapiro-Wilk test, assuming normality, and using the Fisher tests, assuming variance homogeneity $(P<0.05)$. When $\mathrm{F}$ values were significant $(P<0.05)$, the data were subjected to regression analysis, and equations were adjusted using the linear and polynomial models of the SigmaPlot 14.0 statistical package (Systat Software Inc., USA). Mean values were compared using Tukey's HSD test $(P<0.05)$. For data interpretation, the equations with significance $(P<0.05)$ and the highest coefficients of determination $\left(\mathrm{R}^{2}\right)$ were selected.

\section{Results}

\subsection{Changes in Inorganic Nitrogen Production Related to Different Urban Waste Compost Amendments}

The ANOVA revealed a significant interaction between soils and UWC doses on inorganic $\mathrm{N}$ content (INC) during the 84-day incubation period $(P<0.0001$; Table 1$)$. The INC showed a linear increase with incubation time in the three soils used, related to the increasing UWC doses. The highest dose of UWC $\left(50 \mathrm{mg} \mathrm{dm}^{-3}\right)$ at all incubation times provided a higher INC than the other UWC doses $\left(12.5,25.0\right.$, and $\left.37.5 \mathrm{mg} \mathrm{dm}^{-3}\right)$. The OS soil accumulated more INC and showed a significant difference $(P<0.0013)$ in comparison to the QS and US soils; however, the US soil was superior to the QS soil (Table 1).

Table 1. Nitrogen mineralization, reflected as total inorganic $\mathrm{N}$ content ( $\mu \mathrm{g} \mathrm{N} \mathrm{g}^{-1}$ soil), in response to the application of urban waste compost (UWC) amendments. Three soils were treated with different UWC doses during an 84-day incubation experiment.

\begin{tabular}{llc}
\hline Soils & UWC & Incubation time (days) \\
\cline { 2 - 3 } & & \\
\hline
\end{tabular}

Notes: Values are means of four replicates \pm standard deviation (SD). Heat-treated urban waste compost (UWC); initial inorganic $N$ content (0 [IINC]) sandy Ustoxic Quartzipsamment (QS), intermediate-texture Red Ultisol soil (US), clayey Red Oxisol soil (OS). Different normal lowercase letters (e.g., a, b, c) indicate significant differences among UWC doses in the QS soil; different italic lowercase letters (e.g., $a, b, c)$ indicate significant differences among UWC doses in the US soil; different bold lowercase letters (e.g., a, b, c) indicate significant differences among UWC doses in the OS soil, and different uppercase letters (e.g., A, B, C) indicate significant differences 
among the three types of soil at the same UWC doses, according to the Tukey test. (F values and $* * P<0.01 \mathrm{from}$ the ANOVA).

\subsection{Changes in Net Nitrogen Mineralized in Response to Different UWC Amendments}

We found significant interactions between soils and UWC doses on NNM during the 84-day incubation period (Table 2). The amount of NNM increased linearly as UWC doses increased in the three soils used. The NNM content was higher at the highest UWC dose $\left(50 \mathrm{mg} \mathrm{dm}^{-3}\right)$ than the other UWC treatments. The OS soil showed higher amounts of NNM compared with the other soils, whereas the US soil was superior to the QS soil (Table 2).

Table 2. Net nitrogen mineralized (NNM) $\left(\mu \mathrm{g} \mathrm{N} \mathrm{g}^{-1}\right.$ soil day $\left.{ }^{-1}\right)$ in three soils treated with urban waste compost (UWC) doses during an 84-day incubation experiment. 
Soils UWC Incubation time (days)

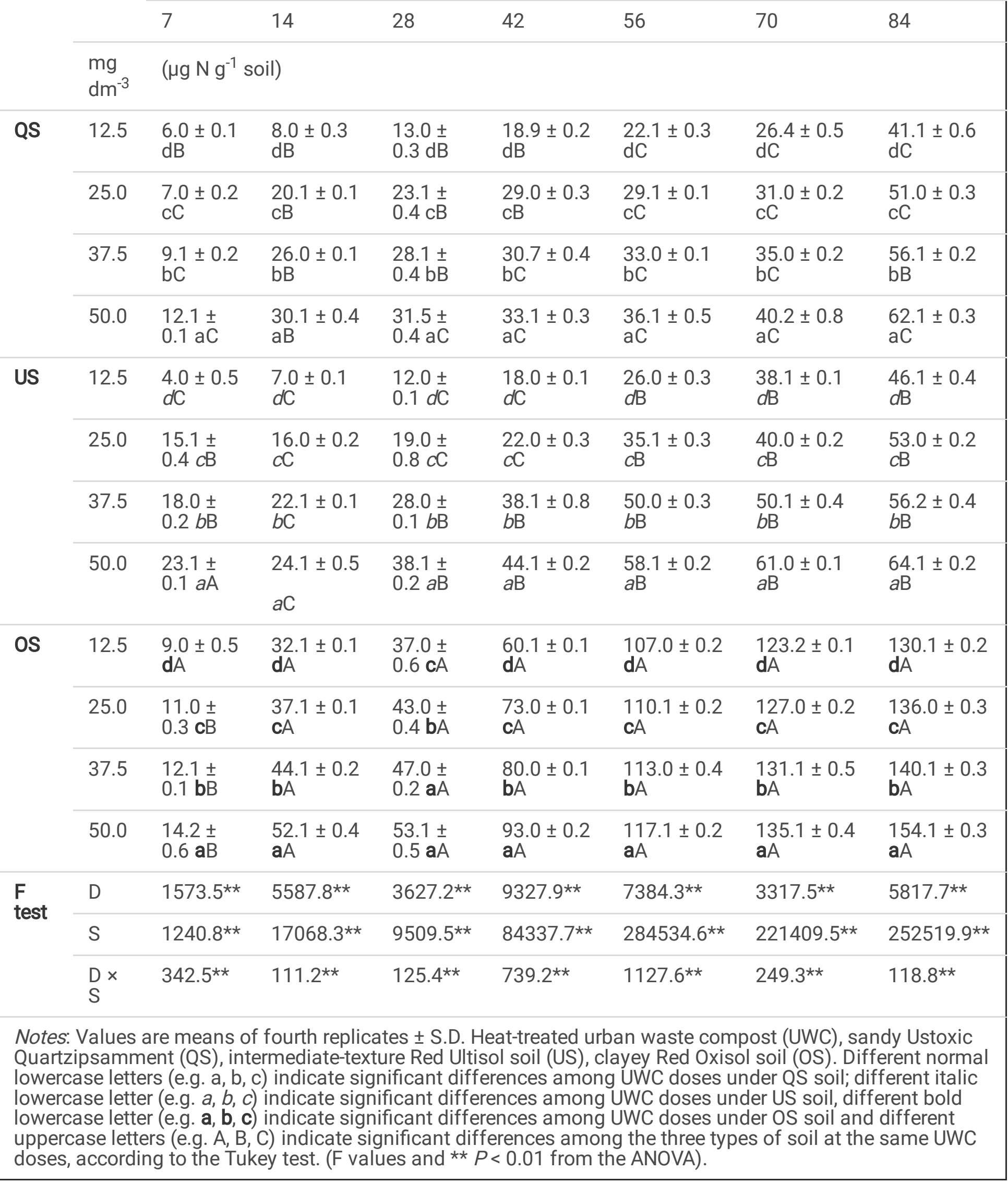




\subsection{Changes in Total Nitrogen Mineralization Rate in Response to Different UWC Amendments}

The UWC application at the highest dose increased the potentially mineralizable $\mathrm{N}\left(\mathrm{N}_{0}\right)$ in the three soils used. These increases were 18,47 , and $27 \%$ in the QS, US, and OS soils, respectively (Table 3 ). In addition, NM was positively correlated (as a power function) with soil type, as occurred in the QS $\left(R^{2}=0.71\right.$ to 0.81$), U S\left(R^{2}=0.70\right.$ to 0.89 ), and OS $\left(R^{2}=0.80\right.$ to 0.89$)$ soils, in relation to the amount of UWC applied (Table 3 ).

Table 3. Nitrogen mineralization rate in three soils treated with different urban waste compost (UWC) doses after 84-day incubation experiment. 


\begin{tabular}{|c|c|c|c|c|c|}
\hline \multirow[t]{2}{*}{ Soils } & UWC & $\mathrm{N}_{0}$ & $\mathrm{R}^{2}$ & NMR & TNM \\
\hline & $\left(\mathrm{mg} \mathrm{dm} \mathrm{m}^{-3}\right)$ & $\left(\mu \mathrm{g} \mathrm{N} \mathrm{g}^{-1}\right)$ & & $\left(\mu \mathrm{g} \mathrm{N} \mathrm{g}^{-1}\right.$ soil $\left.^{-1}\right)$ & $(\%)$ \\
\hline \multirow[t]{4}{*}{ US } & 12.5 & $32.4 \pm 0.3 \mathrm{dC}$ & 0.75 & $129.6 \pm 1.1 \mathrm{dC}$ & $56.1 \pm 0.3 \mathrm{dA}$ \\
\hline & 25.0 & $34.6 \pm 0.3 \mathrm{cC}$ & 0.81 & $139.4 \pm 0.5 c C$ & $62.7 \pm 0.7 \mathrm{cB}$ \\
\hline & 37.5 & $39.5 \pm 0.4 \mathrm{bc}$ & 0.78 & $141.3 \pm 0.7 \mathrm{bC}$ & $82.1 \pm 0.3 \mathrm{bA}$ \\
\hline & 50.0 & $43.6 \pm 0.3 \mathrm{aC}$ & 0.80 & $150.5 \pm 0.6 \mathrm{aC}$ & $89.3 \pm 0.6 \mathrm{aA}$ \\
\hline \multirow[t]{4}{*}{ RS } & 12.5 & $45.4 \pm 0.3 d \mathrm{~dB}$ & 0.70 & $136.3 \pm 0.6 \mathrm{~dB}$ & $42.3 \pm 0.3 d C$ \\
\hline & 25.0 & $49.4 \pm 0.3 \mathrm{cB}$ & 0.83 & $149.4 \pm 0.4 c \mathrm{~B}$ & $51.2 \pm 0.2 c C$ \\
\hline & 37.5 & $59.4 \pm 0.4 b \mathrm{~B}$ & 0.83 & $155.1 \pm 0.6 b \mathrm{~B}$ & $52.3 \pm 0.5 b C$ \\
\hline & 50.0 & $65.4 \pm 0.2 \mathrm{aB}$ & 0.89 & $167.3 \pm 0.4 \mathrm{aB}$ & $71.3 \pm 0.4 a C$ \\
\hline \multirow[t]{4}{*}{ os } & 12.5 & $74.3 \pm 0.9 \mathrm{bA}$ & 0.80 & $170.8 \pm 0.6 \mathrm{dA}$ & $53.3 \pm 0.3 \mathrm{~dB}$ \\
\hline & 25.0 & $75.5 \pm 0.3 \mathrm{bA}$ & 0.81 & $176.1 \pm 0.2 \mathrm{cA}$ & $64.3 \pm 0.5 \mathrm{cA}$ \\
\hline & 37.5 & $84.5 \pm 0.7 \mathrm{aA}$ & 0.83 & $180.4 \pm 0.4 \mathrm{bA}$ & $71.3 \pm 0.3 \mathrm{bB}$ \\
\hline & 50.0 & $85.2 \pm 0.5 \mathrm{aA}$ & 0.89 & $194.6 \pm 0.6 \mathrm{aA}$ & $80.5 \pm 0.2 \mathrm{aB}$ \\
\hline \multirow[t]{3}{*}{$F$ test } & D & $1164.5^{\star \star}$ & & $2419.1^{\star \star}$ & $13320.8^{\star \star}$ \\
\hline & S & $16170.0^{\star *}$ & & $12642.3^{\star \star}$ & $7441.4^{\star \star}$ \\
\hline & $D \times S$ & $51.9 * \star$ & & $56.8^{\star \star *}$ & $257.6^{\star \star}$ \\
\hline \multicolumn{6}{|c|}{$\begin{array}{l}\text { Notes: Values are means of fourth replicates } \pm \text { S.D. Heat-treated urban waste compost (UWC), sandy Ustoxic } \\
\text { Quartzipsamment (QS), intermediate-texture Red Ultisol soil (US), clayey Red Oxisol soil (OS). Different normal } \\
\text { lowercase letters (e.g. a, b, c) indicate significant differences among UWC doses under QS soil; different italic } \\
\text { lowercase letter (e.g. a, b, c) indicate significant differences among UWC doses under US soil, different bold } \\
\text { lowercase letter (e.g. a, b, c) indicate significant differences among UWC doses under OS soil and different } \\
\text { uppercase letters (e.g. A, B, C) indicate significant differences among the three types of soil at the same UWC } \\
\text { doses, according to the Tukey test. F values and ** } P<0.01 \text { from the ANOVA). Initial amount of mineral } N\left(N_{0}\right) \\
\text { coefficient of determination }\left(R^{2}\right), N \text { mineralization rate (NMR), percentage } N \text { mineralization after } 84 \text { days } \\
\text { (TNM). }\end{array}$} \\
\hline
\end{tabular}

The cumulative NM in the 84-day incubation period was higher for the OS soil (194.6 $\pm 0.6 \mu \mathrm{g} \mathrm{N} \mathrm{g}^{-1}$ soil), followed by the US $(167.3 \pm 0.4 \mu \mathrm{g} \mathrm{N} \mathrm{g}-1$ soil), and QS $(150.5 \pm 0.6 \mu \mathrm{g} \mathrm{N} \mathrm{g}-1$ soil) soils. The percentage of TNM increased as the UWC dose increased in the three soils. The high UWC doses increased the TNM by $72 \%, 54 \%$, and $66 \%$ in the QS, US, and OS soils, respectively. The TNM varied from $42 \%$ to $89 \%$ after 84 days of incubation, depending on the applied UWC dose and soil type (Table 3).

\subsection{Changes in Soil Properties in Response to Urban Waste Compost and Urea Treatments}


The data illustrated in Fig. 1 clearly show that $\mathrm{pH}$ values and $\mathrm{Ca}, \mathrm{Mg}$, and $\mathrm{P}$ concentrations had a significant linear response to the increase in UWC doses (Fig. 1a-e); however, the concentration of $\mathrm{H}+\mathrm{Al}$ showed a significantly decreased quadratic response (Fig. 1b). Conversely, the application of urea decreased linearly $\mathrm{pH}$ values whereas the $\mathrm{H}+\mathrm{Al}$ increased linearly (Fig. 1b) and did not significantly affect $\mathrm{Ca}, \mathrm{Mg}$ and $\mathrm{P}$ concentrations (Fig. 1c-e). At all doses of $\mathrm{N}$, except at $12.5 \mathrm{mg} \mathrm{dm}^{-3}$, the use of UWC provided higher values for $\mathrm{pH}$ and $\mathrm{Ca}, \mathrm{Mg}$, and $\mathrm{P}$ concentrations (Fig. 1a-e) and lower concentrations of $\mathrm{H}+\mathrm{Al}$ (Fig. 1b) compared to the urea fertilizer.

\subsection{Changes in Lettuce and Broccoli Production in Response to Urban Waste Compost and Urea Treatments}

Increased doses of UWC and urea applied to the soil resulted in a linear increase in the concentrations of $\mathrm{N}$ in broccoli and lettuce plants (Fig. 2a, b). In both cultures, the application of UWC promoted a higher concentration of $\mathrm{N}$ in the leaves compared to the foliar $\mathrm{N}$ concentrations associated with the urea applications, except at a dose of $25 \mathrm{mg} \mathrm{dm}^{-3}$ of $\mathrm{N}$, which showed no difference between the sources of $\mathrm{N}$ (Fig. 2a, b). In contrast, for the $12.5 \mathrm{mg}$ $\mathrm{dm}^{-3}$ dose, urea produced higher concentrations of $\mathrm{N}$ in the broccoli plants than produced by the UWC (Fig. 2a). In both cultivated species, there was an increase in $\mathrm{N}$ accumulation with linear adjustment as a function of $\mathrm{N}$ doses and the forms of UWC and urea (Fig. 2c, d). In broccoli plants, the two highest doses of UWC resulted in greater $\mathrm{N}$ accumulation compared to urea, and the opposite occurred at the lowest dose of N (Fig. 2c). However, in lettuce plants, the application of $\mathrm{N}$ in the form of UWC, relative to the urea, provided greater $\mathrm{N}$ accumulation in all studied $\mathrm{N}$ doses (Fig. 2d).

The application of $\mathrm{N}$ doses as two $\mathrm{N}$ sources promoted a linear increase in the production of the fresh mass of broccoli plants (Fig. 3a). The application of UWC only, at the two highest $\mathrm{N}$ doses, resulted in greater production of fresh mass from the broccoli plants compared to the application of urea (Fig. 3a). In lettuce plants, the application of both sources of $\mathrm{N}$ promoted increments with quadratic adjustment in the production of fresh mass, reaching the maximum point at $\mathrm{N}$ doses equal to 37.5 and $25 \mathrm{mg} \mathrm{dm}^{-3}$ for UWC and urea, respectively (Fig. $3 b$ ). The use of UWC, in comparison with urea application only, for the two highest doses of N employed, resulted in greater production of the fresh mass of lettuce plants (Fig. 3b).

\section{Declarations}

Funding. The project was financially supported by the Centro Universitario da Fundação Educacional de Barretos UNIFEB - Brasil.

Conflicts of interest/Competing interests. The authors declare there are no competing interests.

Availability of data and material. The following information was supplied regarding data availability: Dates of Physicochemical characteristics of the studied soils and heat-treated urban waste compost, and the parameter values for calculation of the $\mathrm{N}$ mineralization rate are provided in the Supplemental Files. 
Code availability. 'Not applicable'

Authors' contributions. Conceived and designed the experiments: FON, RMP, HAS, and MGA. Performed the lab experiment: FON, HAS, and MGA. Performed the greenhouse experiments: FON, MGA, ACH, LFP and LASND. Analyzed the data: FON, RMP, HAS, and $\mathrm{ACH}$. All authors discussed the conceptual model and contributed to data interpretation and the writing of the paper.

\section{References}

1. Roy, T.K., Saroar, M.M., Haque, S.M.: Use of Co-compost from faecal sludge and Municipal organic waste in urban green space plantation of Khulna City: prospects and problems. In: Ghosh, S. (ed.) Waste Valorisation and Recycling, pp. 179-191. Springer Singapore, Singapore (2019)

2. Glaesner, N., van der Bom, F., Bruun, S., McLaren, T., Larsen, F.H., Magid, J.: Phosphorus characterization and plant availability in soil profiles after long-term urban waste application. Geoderma. 338, 136-144 (2019). https://doi.org/10.1016/J.GEODERMA.2018.11.046

3. Patwa, A., Parde, D., Dohare, D., Vijay, R., Kumar, R.: Solid waste characterization and treatment technologies in rural areas: An Indian and international review. Environ. Technol. Innov. 20, 101066 (2020). https://doi.org/10.1016/j.eti.2020.101066

4. Melikoglu, M.: Reutilisation of food wastes for generating fuels and value added products: A global review. Environ. Technol. Innov. 19, 101040 (2020). https://doi.org/10.1016/j.eti.2020.101040

5. Flavel, T.C., Murphy, D.V.: Carbon and Nitrogen Mineralization Rates after Application of Organic Amendments to Soil. J. Environ. Qual. 35, 183-193 (2006). https://doi.org/10.2134/jeq2005.0022

6. Domínguez, M., Paradelo Núñez, R., Piñeiro, J., Barral, M.T.: Physicochemical and biochemical properties of an acid soil under potato culture amended with municipal solid waste compost. Int. J. Recycl. Org. Waste Agric. 8, 171-178 (2019). https://doi.org/10.1007/s40093-019-0246-x

7. Bhat, S., Singh, S., Singh, J., Kumar, S., Bhawana, B., Vig, A.: Bioremediation and detoxification of industrial wastes by earthworms: Vermicompost as powerful crop nutrient in sustainable agriculture. Bioresour. Technol. 252, 172-179 (2018). https://doi.org/10.1016/J.BIORTECH.2018.01.003

8. Miezah, K., Obiri-Danso, K., Kádár, Z., Fei-Baffoe, B., Mensah, M.Y.: Municipal solid waste characterization and quantification as a measure towards effective waste management in Ghana. Waste Manag. 46, 15-27 (2015). https://doi.org/10.1016/J.WASMAN.2015.09.009

9. Liang, B., Yang, X., He, X., Murphy, D.V., Zhou, J.: Long-term combined application of manure and NPK fertilizers influenced nitrogen retention and stabilization of organic C in Loess soil. Plant Soil. 353, 249-260 (2012). https://doi.org/10.1007/s11104-011-1028-z

10. Naderi, R., Edalat, M., Egan, T.P.: Effects of urea nitrogen and residual composted municipal waste and sheep manure on the growth and chemical composition of two triticale genotypes. J. Plant Nutr. 41, 178-185 (2017). https://doi.org/10.1080/01904167.2017.1382527

11. Chrysargyris, A., Stamatakis, A., Moustakas, K., Prasad, M., Tzortzakis, N.: Evaluation of Municipal Solid Waste Compost and/or Fertigation as Peat Substituent for Pepper Seedlings Production. Waste and Biomass Valorization. 9, 2285-2294 (2018). https://doi.org/10.1007/s12649-017-0124-6

12. Basta, N.T., Ryan, J.A., Chaney, R.L.: Trace element chemistry in residual-treated soil: Key concepts and metal bioavailability. J. Environ. Qual. 34, 49-63 (2005). https://doi.org/10.2134/jeq2005.0049dup 
13. Manirakiza, E., Ziadi, N., St. Luce, M., Hamel, C., Antoun, H., Karam, A.: Nitrogen mineralization and microbial biomass carbon and nitrogen in response to co-application of biochar and paper mill biosolids. Appl. Soil Ecol. 142, 90-98 (2019). https://doi.org/10.1016/j.apsoil.2019.04.025

14. Masunga, R.H., Uzokwe, V.N., Mlay, P.D., Odeh, I., Singh, A., Buchan, D., De Neve, S.: Nitrogen mineralization dynamics of different valuable organic amendments commonly used in agriculture. Appl. Soil Ecol. 101, 185-193 (2016). https://doi.org/10.1016/j.apsoil.2016.01.006

15. Manojlović, M., Čabilovski, R., Bavec, M.: Organic materials: sources of nitrogen in the organic production of lettuce. Turkish J. Agric. For. 34, 163-172 (2010). https://doi.org/10.3906/tar-0905-11

16. Fascella, G., Montoneri, E., Ginepro, M., Francavilla, M.: Effect of urban biowaste derived soluble substances on growth, photosynthesis and ornamental value of Euphorbia x lomi. Sci. Hortic. (Amsterdam). 197, 90-98 (2015). https://doi.org/10.1016/j.scienta.2015.10.042

17. Carbonell, G., de Imperial, R.M., Torrijos, M., Delgado, M., Rodriguez, J.A.: Effects of municipal solid waste compost and mineral fertilizer amendments on soil properties and heavy metals distribution in maize plants (Zea mays L.). Chemosphere. 85, 1614-1623 (2011). https://doi.org/10.1016/j.chemosphere.2011.08.025

18. Mantovani, J.R., Ferreira, M.E., Cruz, M.C.P., da, Barbosa, J.C., Freiria, A.C.: Mineralização de carbono e de nitrogênio provenientes de composto de lixo urbano em argissolo. Rev. Bras. Ciência do Solo. 30, 677-684 (2006). https://doi.org/10.1590/S0100-06832006000400008

19. Cordovil, C.M.d.S., Coutinho, J., Goss, M., Cabral, F.: Potentially mineralizable nitrogen from organic materials applied to a sandy soil: fitting the one-pool exponential model. Soil Use Manag. 21, 65-72 (2006). https://doi.org/10.1111/j.1475-2743.2005.tb00108.x

20. Øvsthus, I., Breland, T.A., Hagen, S.F., Brandt, K., Wold, A.B., Bengtsson, G.B., Seljåsen, R.: Effects of organic and waste-derived fertilizers on yield, nitrogen and glucosinolate contents, and sensory quality of broccoli (Brassica oleracea L. var. italica). J. Agric. Food Chem. 63, 10757-10767 (2015). https://doi.org/10.1021/acs.jafc.5b04631

21. Santos, F.T., Goufo, P., Santos, C., Botelho, D., Fonseca, J., Queirós, A., Costa, M.S.S.M., Trindade, H.: Comparison of five agro-industrial waste-based composts as growing media for lettuce: Effect on yield, phenolic compounds and Vitamin C. Food Chem. 209, 293-301 (2016). https://doi.org/10.1016/j.foodchem.2016.04.087

22. WRB: World reference base for soil resources 2014 (update 2015), international soil classification system for naming soils and creating legends for soil maps., Rome, Italia: (2015)

23. van Raij, B., Andrade, J.C., Cantarella, H., Quaggio, J.: Análise química para avaliação da fertilidade de solos tropicais. Instituto Agronômico, Campinas (2001) Campinas

24. Embrapa: Manual de métodos de análises químicas de solos. Embrapa-CNPS, Rio de Janeiro (1997)

25. Abreu, M.F., Silva, H.A.J.C., Santos, F.C., Andrade, G.C.G., Gomes, J.C., Coscione, T.F., Andrade, A.R.: C..: Análise química de fertilizantes orgânicos (urbanos). In: Silva, F. (ed.) Manual de análises químicas de solos, plantas e fertilizantes, pp. 397-486. Embrapa Informação Tecnológica, Brasília (2009)

26. BRASIL: Normas sobre as especificações e as garantias, as tolerâncias, o registro, a embalagem e a rotulagem dos fertilizantes orgânicos simples, mistos, compostos, organominerais e biofertilizantes destinados à agricultura. Ministério da Agricultura Pecuária e Abastecimento, Brazil (2009)

27. Coscione, A.R., Andrade, C.: Protocolos para a avaliação dinâmica de resíduos orgânicos no solo. In: Andrade, J.C., Abreu, M.F. (eds.) Análise química de resíduos sólidos para monitoramento e estudos 
agroambientais, pp. 159-177. Instituto Agronômico, Campinas (2006) Campinas

28. Cantarella, H., Trivelin, P.C.: Determinação de nitrogênio inorgânico em solo pelo método da destilação a vapor. In: van Raij, B., Andrade, J.C., Cantarella, H., Quaggio, J. (eds.) Análise química para avaliação da fertilidade de solos tropicais, pp. 270-276. Instituto Agronômico, Campinas (2011) Campinas

29. Mohanty, M., Reddy, K.S., Probert, M.E., Dalal, R.C., Rao, A.S., Menzies, N.W.: Modelling N mineralization from green manure and farmyard manure from a laboratory incubation study. Ecol. Modell. 222, 719-726 (2011). https://doi.org/10.1016/j.ecolmodel.2010.10.027

30. Azeez, J.O., Van Averbeke, W.: Nitrogen mineralization potential of three animal manures applied on a sandy clay loam soil. Bioresour. Technol. 101, 5645-5651 (2010). https://doi.org/10.1016/j.biortech.2010.01.119

31. Trani, P.E., Raij, B.: Recomendações de adubação e calagem para o Estado de São Paulo. Instituto Agronômico/ Fundação, I.A.C., (Boletim Técnico, 100), Campinas: (1997)

32. Bataglia, O.C., Teixeira, J.P.F., Furlani, P.R., Furlani, A.M.C., Gallo, J.R.: Métodos de análise química de plantas. Instituto Agronômico de Campinas, Campinas (1983)

33. Giusquiani, P.L., Pagliai, M., Gigliotti, G., Businelli, D., Benetti, A.: Urban Waste Compost: Effects on Physical, Chemical, and Biochemical Soil Properties. J. Environ. Qual. 24, 175 (1995). https://doi.org/10.2134/jeq1995.00472425002400010024x

34. Mamo, M., Molina, J.A.E., Rosen, C.J., Halbach, T.R.: Nitrogen and carbon mineralization in soil amended with municipal solid waste compost. In: Canadian Journal of Soil Science. pp. 535-542. Agricultural Institute of Canada: (1999)

35. Tognetti, C., Mazzarino, M.J., Laos, F.: Compost of municipal organic waste: Effects of different management practices on degradability and nutrient release capacity. Soil Biol. Biochem. 40, 2290-2296 (2008). https://doi.org/10.1016/j.soilbio.2008.05.006

36. Schmatz, R., Recous, S., Aita, C., Tahir, M.M., Schu, A.L., Chaves, B., Giacomini, S.J.: Crop residue quality and soil type influence the priming effect but not the fate of crop residue C. Plant Soil. 414, 229-245 (2017). https://doi.org/10.1007/s11104-016-3120-x

37. Campos, A., Suárez, M., Laborde, G.: J.: Analyzing vegetation cover-induced organic matter mineralization dynamics in sandy soils from tropical dry coastal ecosystems. Catena. 185, 104264 (2020). https://doi.org/10.1016/j.catena.2019.104264

38. Martínez, J.M., Galantini, J.A., Duval, M.E., Landriscini, M.R., García, R.J., López, F.: Nitrogen mineralization indicators under semi-arid and semi-humid conditions: influence on wheat yield and nitrogen uptake. Commun. Soil Sci. Plant Anal. 49, 1907-1921 (2018). https://doi.org/10.1080/00103624.2018.1485931

39. Hassink, J., Bouwman, L.A., Zwart, K.B., Bloem, J., Brussaard, L.: Relationships between soil texture, physical protection of organic matter, soil biota, and $\mathrm{C}$ and $\mathrm{N}$ mineralization in grassland soils. In: Soil Structure/Soil Biota Interrelationships. pp. 105-128. Elsevier: (1993)

40. Sigurdarson, J.J., Svane, S., Karring, H.: The molecular processes of urea hydrolysis in relation to ammonia emissions from agriculture. Rev. Environ. Sci. Biotechnol. 17, 241-258 (2018). https://doi.org/10.1007/s11157-018-9466-1

41. Mehmood, K., Baquy, M.A.-A., Xu, R.: Influence of nitrogen fertilizer forms and crop straw biochars on soil exchange properties and maize growth on an acidic Ultisol. Arch. Agron. Soil Sci. 64, 834-849 (2018). https://doi.org/10.1080/03650340.2017.1385062 
42. Tanong, K., Xu, J., Shon, H.: Microbial community analysis of an aerobic nitrifying-denitrifying MBR treating ABS resin wastewater. Bioresour. Technol. 102, 5337-5344 (2011).

https://doi.org/10.1016/J.BIORTECH.2010.12.045

43. Fitzstevens, M.G., Sharp, R.M., Brabander, D.J.: Biogeochemical characterization of municipal compost to support urban agriculture and limit childhood lead exposure from resuspended urban soils. Elem Sci Anth. 5, 1-14 (2017). https://doi.org/10.1525/elementa.238

44. Szymański, K., Janowska, B., Sidełko, R.: The estimate of bioavailability of copper, lead and zinc in municipal solid waste and compost. Asian J. Chemestry. 17, 1646-1660 (2005)

45. Wong, M.T.F., Nortcliff, S., Swift, R.S.: Method for determining the acid ameliorating capacity of plant residue compost, urban waste compost, farmyard manure, and peat applied to tropical soils. Commun. Soil Sci. Plant Anal. 29, 2927-2937 (1998). https://doi.org/10.1080/00103629809370166

46. Strojaki, T.V., Silva, V.R., Somavilla, A., Da Ros, C.O., Moraes, M.T.: Atributos químicos do solo e produtividade de girassol e milho em função da aplicação de composto de lixo urbano. Pesqui. Agropecuária Trop. 43, 278-285 (2013)

47. Hamdi, H., Hechmi, S., Khelil, M.N., Zoghlami, I.R., Benzarti, S., Mokni-Tlili, S., Hassen, A., Jedidi, N.: Repetitive land application of urban sewage sludge: Effect of amendment rates and soil texture on fertility and degradation parameters. Catena. 172, 11-20 (2019). https://doi.org/10.1016/j.catena.2018.08.015

48. Zaman, G., Murtaza, B., Imran, M., Shahid, M., Shah, G.M., Amjad, M., Naeem, M.A., Mubeen, M., Murtaza, G.: Utilization of bio-municipal solid waste improves saline-sodic soils and crop productivity in rice-wheat. Compost Sci. Util. 1-12 (2020). https://doi.org/10.1080/1065657X.2019.1709106

49. Ernani, P.R., Nascimento, J.A.L., Campos, M.L., Camillo, R.J.: Influência da combinação de fósforo e calcário no rendimento de milho. Rev. Bras. Ciência Solo. 24, 537-544 (2000). https://doi.org/10.1590/s010006832000000300007

50. Noirot-Cosson, P.E., Vaudour, E., Gilliot, J.M., Gabrielle, B., Houot, S.: Modelling the long-term effect of urban waste compost applications on carbon and nitrogen dynamics in temperate cropland. Soil Biol. Biochem. 94, 138-153 (2016). https://doi.org/10.1016/j.soilbio.2015.11.014

51. Maftoun, M., Moshiri, F., Karimian, N., Ronaghi, A.M.: Effects of two organic wastes in combination with phosphorus on growth and chemical composition of spinach and soil properties. J. Plant Nutr. 27, 16351651 (2005). https://doi.org/10.1081/PLN-200026005

52. Erana, F.G., Tenkegna, T.A., Asfaw, S.L.: Effect of agro industrial wastes compost on soil health and onion yields improvements: study at field condition. Int. J. Recycl. Org. Waste Agric. 8, 161-171 (2019). https://doi.org/10.1007/s40093-019-0286-2

\section{Figures}


a)

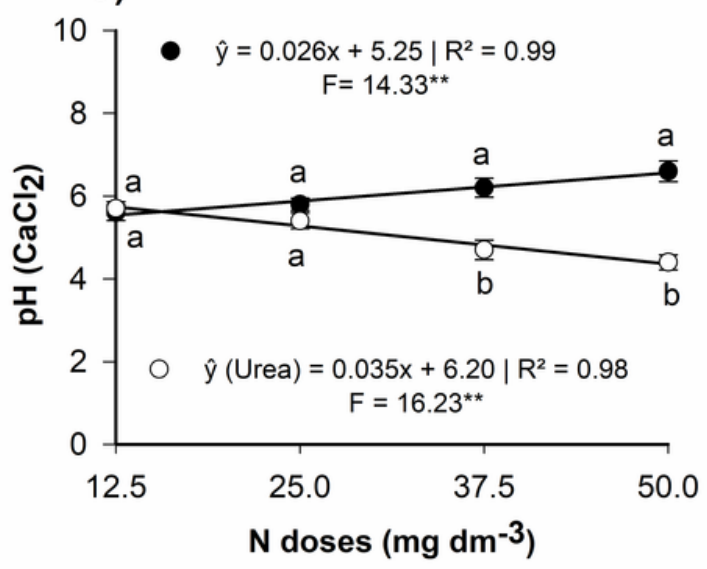

c)

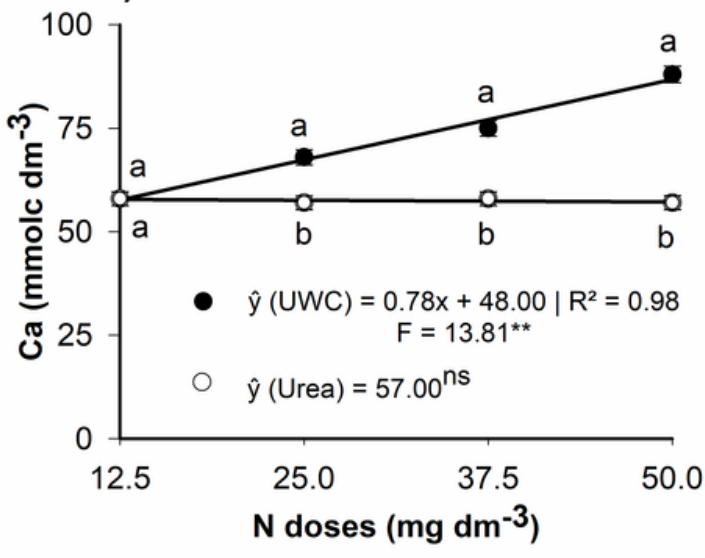

b)

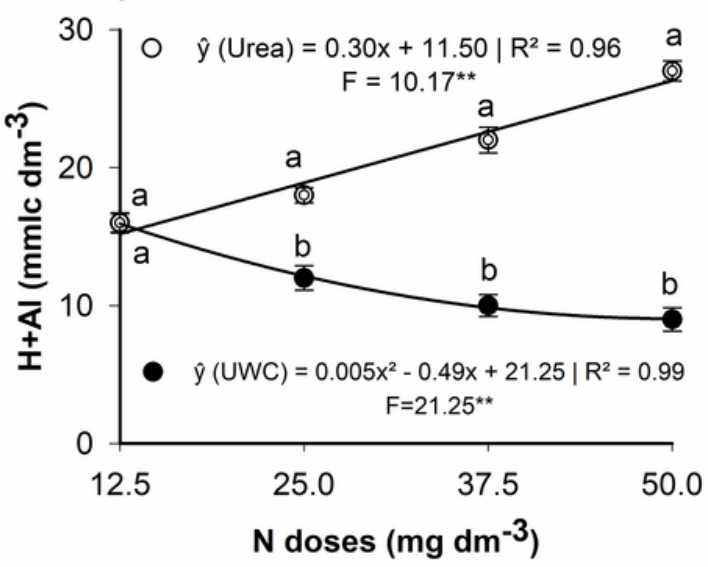

d)

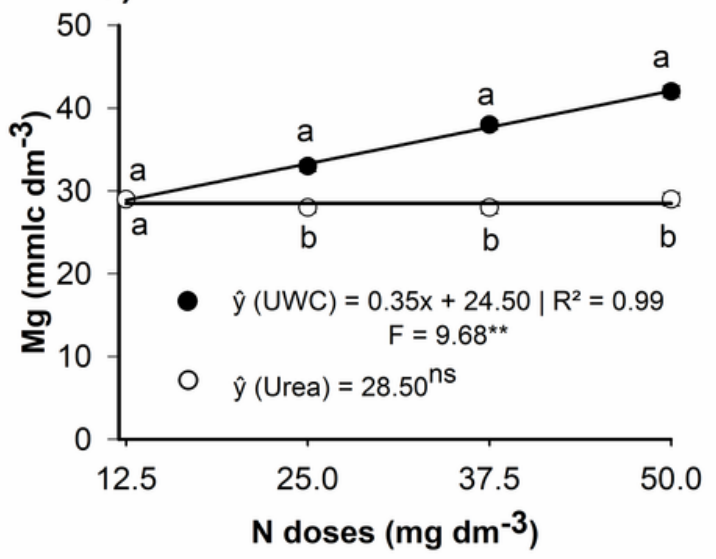

e)

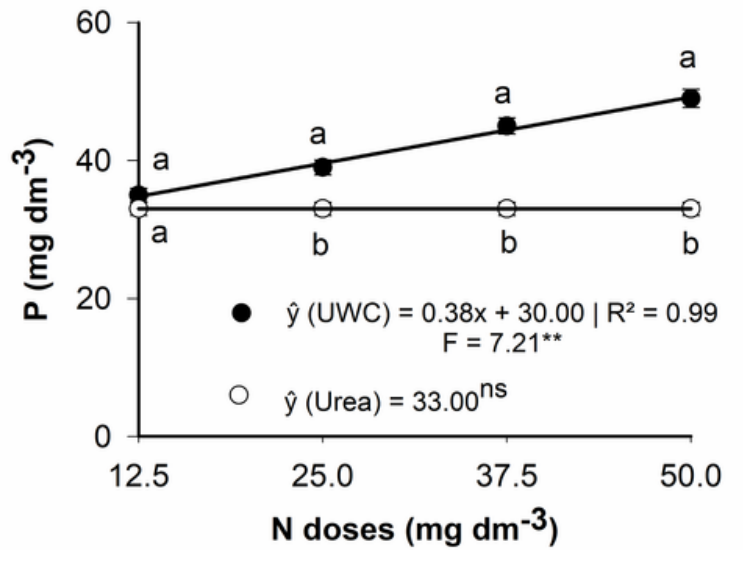

Figure 1

Soil $\mathrm{pH}(\mathrm{a})$ and $\mathrm{H}+\mathrm{Al}(\mathrm{b})$ values, and concentrations of $\mathrm{Ca}(\mathrm{c}), \mathrm{Mg}(\mathrm{d})$, and $\mathrm{P}(\mathrm{e})$, as a function of $\mathrm{N}$ doses (12.5, $25.0,37.5$, and $50.0 \mathrm{mg} \mathrm{dm}-3$ ) and the $\mathrm{N}$ sources (UWC and urea) applied. Values are given as the mean of four replications \pm standard deviation (Means $\pm S D ; n=4$ ). Different lowercase letters indicate significant differences between the different sources of $\mathrm{N}$ at the same doses of $\mathrm{N}$ according to the Tukey test $(\mathrm{P}<0.05)$. ( $\mathrm{F}$ values, ${ }^{*} \mathrm{P}<$ 0.05 , and $* * P<0.01$ from the ANOVA). 

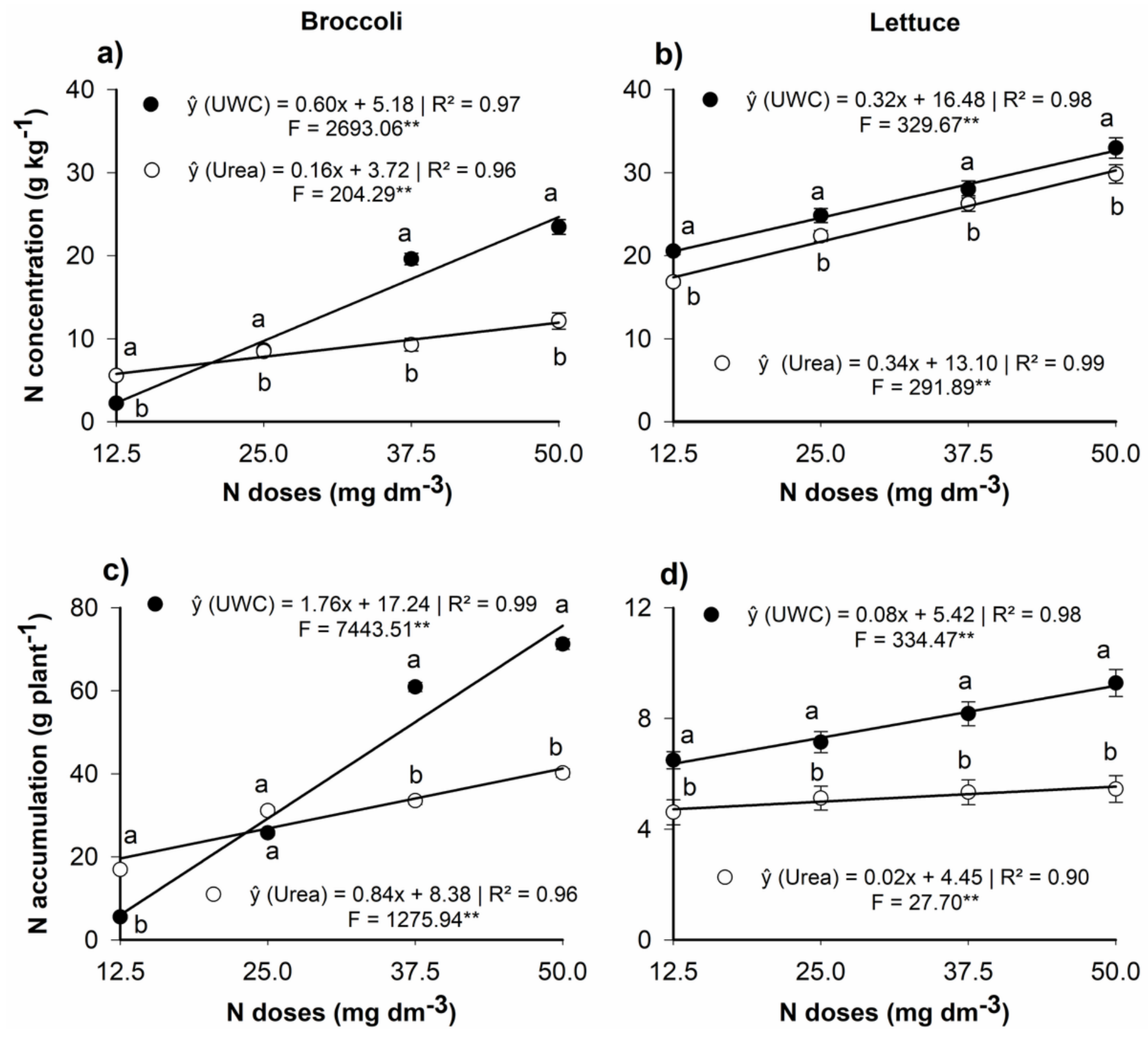

Figure 2

Leaf nitrogen concentration in the aerial parts of broccoli (a) and lettuce plants (b). Nitrogen accumulation in broccoli (c) and lettuce plants (d) as a function of $\mathrm{N}$ doses $(12.5,25.0,37.5$, and $50.0 \mathrm{mg} \mathrm{dm}-3)$ and the $\mathrm{N}$ sources (UWC and urea) applied. Means \pm S.D.; $n=4$. Different lowercase letters indicate significant differences between the different sources of $N$ at the same $N$ doses, according to Tukey's test $(P<0.05)$. ( $F$ values from the ANOVA: $P$ $<0.05 ; * \star \mathrm{P}<0.01)$. 
Broccoli

a)

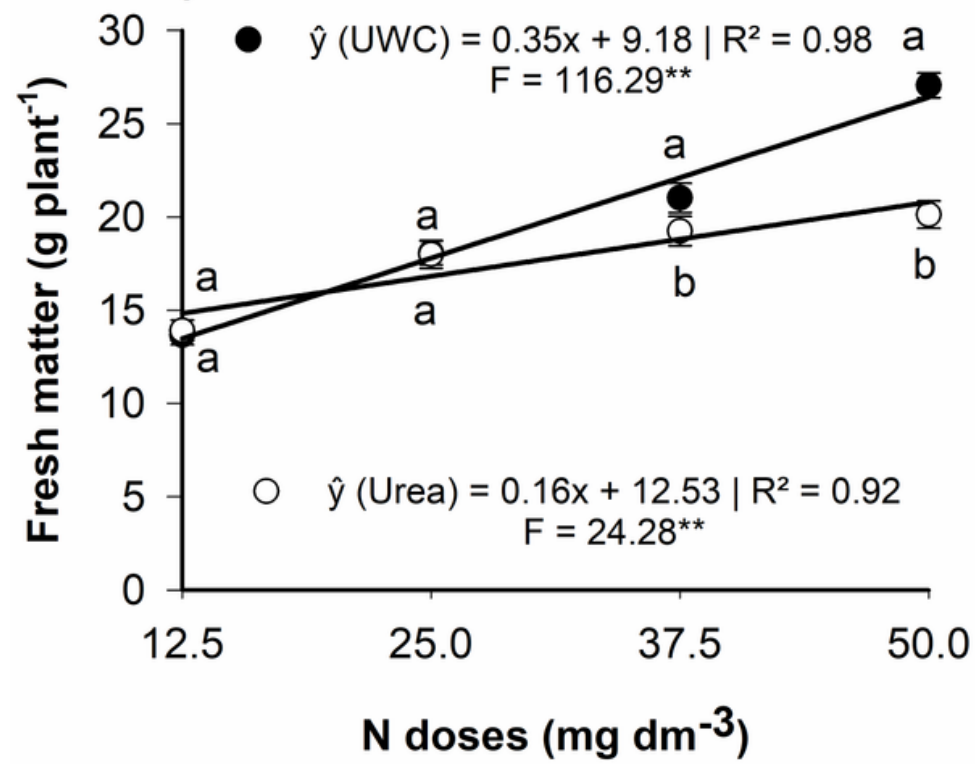

Lettuce

b)

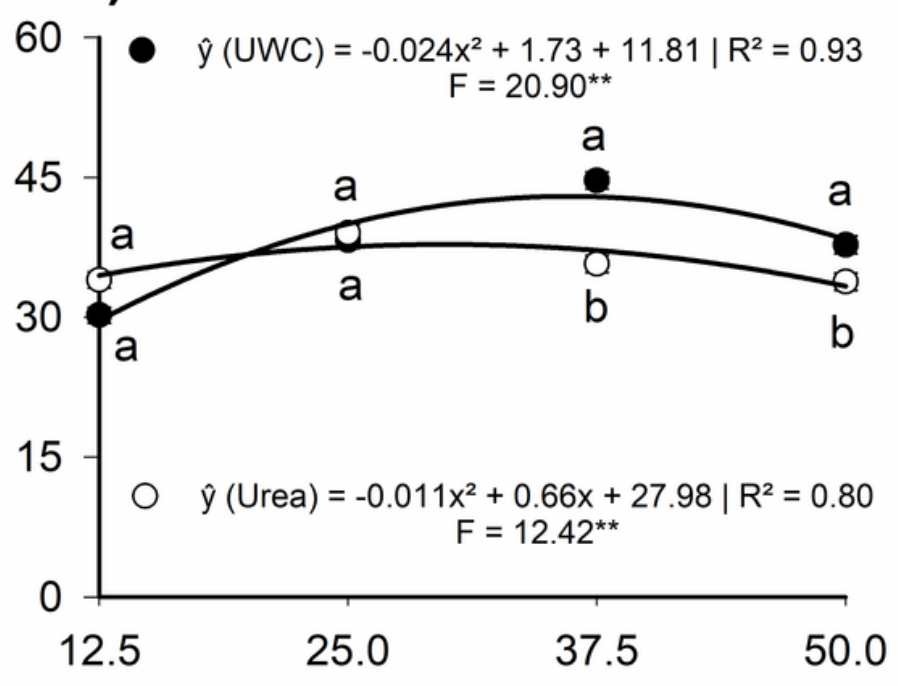

$\mathrm{N}$ doses $\left(\mathrm{mg} \mathrm{dm}^{-3}\right)$

\section{Figure 3}

Fresh biomass production in broccoli (a) and lettuce plants (b) as a function of the $\mathrm{N}$ doses $(12.5,25.0,37.5$, and $50.0 \mathrm{mg} \mathrm{dm}-3$ ) and N sources (UWC and urea) applied. Means \pm S.D.; $n=4$. Different lowercase letters indicate significant differences between the different sources of $\mathrm{N}$ at the same $\mathrm{N}$ doses, according to the Tukey test $(\mathrm{P}<$ 0.05). ( $F$ values, $* P<0.05$, and $* * P<0.01$ from ANOVA).

\section{Supplementary Files}

This is a list of supplementary files associated with this preprint. Click to download.

- Supplementarymaterial.pdf

- Onlinefloatimage1.png 